\title{
Grape seed oil: a potential functional food?
}

\author{
Fernanda Branco SHINAGAWA ${ }^{1}$, Fernanda Carvalho de SANTANA ${ }^{1}$, \\ Lucillia Rabelo Oliveira TORRES ${ }^{1}$, Jorge MANCINI-FILHO ${ }^{1 *}$
}

\begin{abstract}
Grape seed oil (GSO) is not often consumed in Brazil and little is known of its nutritional value. Around the world there are already studies that point to the high levels of minority bioactive compounds and their relation to health benefits. The main constituent of GSO is linoleic fatty acid, some works are controversial and there is no consensus in literature regarding their effect on the animal organism. Thus, this study aimed to present a review of GSO and show the potential health effects of its major components, not only linoleic acid, but also $\gamma$-tocotrienol and $\beta$-sitosterol, and finally, their influence on lipid-modulating, anti and pro oxidative parameters.
\end{abstract}

Keywords: grape seed oil; linoleic acid; tocotrienols; oxidative stress; inflammation.

Practical Application: It is widely known that the consumption of vegetable oils rather than solid fats is vital to maintaining health. In particular, cold pressed grape seed oil stands out as a suitable alternative to other commonly used vegetable oils because of its higher amounts of essential fatty acid, and many others bioactive compounds. And equally importantly, it is an environmentally friendly oil as it is a by-product of wine and grape juice-making processes.

\section{Brazilian grape cultivation}

Archaeological investigation indicates that grapes were cultivated before 4000 BC. However, in Brazil they were introduced only in 1532 during the Portuguese colonization (Camargo et al., 2010). Since Brazilian grape cultivation began, cultivation has occurred mainly in South of the country, especially in Rio Grande do Sul State (Empresa Brasileira de Pesquisa Agropecuária, 2013; Freitas et al., 2008).

In 2011, approximately $42 \%$ of grape total production was marketed as fresh grape fruit and $57 \%$ was destined for processing to obtain wine and juice (Mello, 2011). According to Camargo et al. (2010) there are a large number of cultivars in Brazil, among them, Vitis Vinifera, Vitis Labrusca more frequently found and around 40 American grape cultivars.

Brazilian grape cultivation focuses on wine production. Latest data from the United Nations Organization for Food and Agriculture (Food and Agriculture Organization, 2012) shows Brazil was the $11^{\text {th }}$ largest grape producer in the world, dates from 2011 , and its harvest corresponded to approximately 1.5 million tons of grapes; i.e., 80,003 ha of area produced throughout national territory (Instituto Brasileiro de Geografia e Estatística, 2012). Rio Grande do Sul State as the biggest national producer, responsible for 829,589 tons of grape production per year, which represents approximately $55 \%$ of total Brazilian cultivation (Empresa Brasileira de Pesquisa Agropecuária, 2013).

\section{Grape seed: an agro-industrial waste}

Nowadays we observe a large expansion of wine production, increasingly biomass residue which, from an environmental point of view, can be used for a beneficial purpose for human beings and the environment (Kobori \& Jorge, 2005). Reusing the biomass residue would solve, at least in part, storage problems and wine by-products. However, the main importance is due to its content is rich in lipids, bioactive compounds (such as vitamin E, phytosterols and phenolics) which is important to food, pharmaceutical/phytotherapy and cosmetics industries (Kim et al., 2013; Rockenbach et al., 2010; Nakamura et al., 2003).

Wine by-product is composed basically of peel, seed and grape stems. In general, peel and grape stems are not economically utilized. However, the seeds are used in the food industry and can create some opportunities to lower production costs and new food source for human consumption (Gokturk Baydar \& Akkurt, 2001). In this context, the seeds appear as a good economical and healthy source. For the industry point of view, the reuse of grape seed is concentrated in the oil and flour. Grape seed flour is the residue from seed oil manufacture and has not receive much attention but may be a potential rich source of natural antioxidant and others healthy compounds as the fiber (Lutterodt et al., 2011).

Current amount of seeds can vary between one and four units per grape. According to Matthäus (2008), in $100 \mathrm{~kg}$ of 
wet residue produced by industry there is about 10 to $12 \mathrm{~kg}$ of seeds obtained. Lipid content of grape seed is around 7 to $20 \%$ (Beveridge et al., 2005; Luque-Rodriguez et al., 2005; Cao \& Ito, 2003). In addition, there are also around 35\% of fiber, $11 \%$ of protein, $3 \%$ of minerals and $7 \%$ of water. Minor compounds concentration can vary, depending on the technological processing performed and many environmental cultivation conditions (Luque-Rodríguez et al., 2005; Schieber et al., 2002).

Grape seed extract (aqueous or alcoholic) are part of agro-industrial residue of wine industry more extensively studied because of its high antioxidant potential (Peralbo-Molina \& Luque de Castro, 2013; Lafka et al., 2007). Beneficial effects of seed extracts include: modulation of antioxidant enzymes expression (Puiggròs et al., 2005); protection against oxidative damage in brain cells of rats (Guo et al., 2007); atherosclerosis in hamsters (Vinson et al., 2002) and some anti-inflammatory effects (Wang et al., 2009). Due to grape seed has a considerable content of phenolic compounds (around 60 to $70 \%$ of the total of minority compound), in smaller percentages in other parts of the fruit, such as in peels (28-35\%), and lower values are found in the pulp (approximately 10\%) (Revilla et al., 1997). Maier et al. (2009) and Shi et al. (2003) identified some phenolics compounds such as some monomers (gallic acid, catechin, epicatechin and epicatechin-3-O-gallato) and wide variety of procyanidins oligomers in grape seed.

\section{Grape seed oil (GSO)}

Vegetable oils are part of human diet, and the search for new sources has to increase since there is a preference to replace animal fats (butter and lard). There is a worldwide trend in new sources searching for vegetable oil, and a lot of research has been carried out around the world for this propose, mainly with fruits seeds such as GSO (Chougui et al., 2013; Parry et al., 2005, 2006).

GSO is quite widespread in Europe and has been manufactured in Germany, France and Italy since 1930 and it is gaining popularity as culinary oil, and has been studied as a possible source of specialty lipids (Camargo et al., 2010).

Cold-pressing is a method of oil extraction that involves no heat or chemical treatment, and hence may retain more health beneficial components, such as natural antioxidants (Parry et al., 2006). The cold-pressed oils may be a better source of beneficial components, such as antioxidative phenolic compounds (Bail et al., 2008), as well as other health-beneficial phytochemicals (Crews et al., 2006). Although the yield is usually lower than that with conventional solvent extraction, there is no concern about solvent residues in the oil, making for a safer and more consumer-desired product.

GSO composition has a high content of polyunsaturated fatty acids (PUFA), in the range of 85 to $90 \%$; among them, linoleic acid (C18:2), exponent of $\mathrm{n}-6$ series has been highlighted (Fernandes et al., 2013). Linoleic acid (LA) is present in abundance in vegetable oils such as sunflower oil (about 60\%), corn (about 52\%) and soybeans (around 50\%) (Tangolar et al., 2009). LA is associated with promotion of cardiovascular health by down-regulating low-density lipoprotein cholesterol (LDL-c) production (Kim et al., 2010).

There are also chemical components in GSO with biological importance due to antioxidant activity (Figure 1). Among them include, phytosterols, tocopherols, tocotrienols, flavonoids, phenolic acids and carotenoids. Most importantly, GSO is source of tocopherols and tocotrienols, isomers of vitamin $\mathrm{E}$ (Fernandes et al., 2013). In their composition it is possible to find vitamin E values, ranging from 1 to $53 \mathrm{mg} / 100 \mathrm{~g}$ oil (Freitas et al., 2008) depending on the grape variety and environmental cultivation conditions (Crews et al., 2006).

Others minority compounds largely found in their compositions are phytosterols (Figure 1). Crews et al. (2006) showed an average between 2.58 and $11.25 \mathrm{mg}$ of phytosterols per gram of oil. This data were confirmed later by Rubio et al. (2009) and Pardo et al. (2009), indicating that $\beta$-sitosterol is the major constituent of phytosterols component in GSO, corresponding an average percentage between 67 and 70\%. Campesterol and stigmasterol are found in the composition, while contents of $\Delta-5$ avenasterol, $\Delta-7$ stigmasterol and $\Delta-7$ avenasterol are low (Matthäus, 2008). Table 1 shows the range of phytosterols composition of GSO from the literature.

Vivancos \& Moreno (2008) observed $\beta$-sitosterol may prevent the release of pro-inflammatory mediators by oxidased low-density lipoprotein-stimulated (oxLDL) macrophage on oxidative stress and eicosanoid synthesis.

Antioxidant capacity present in grape seed is well known, but studies from oil extracted are still not that explored in literature. It becomes interesting to identify and quantify these compounds present in GSO from different parts of the world submitted to different techniques of extraction (refine and cold pressed). There are many studies in the literature about the optimization of extraction process, due to polar affinity (Pinelo et al., 2005).

Evidence in literature shows GSO antioxidant acticity is directly related to the high concentration of vitamin E isomer, namelly $\gamma$-tocotrienol (Fernandes et al., 2013; Madawala et al., 2012; Freitas et al., 2008; Crews et al., 2006) which is rarely found in other oils. Table 2 shows the range of tocopherol and tocotrienol composition of GSO from the literature.

Studies have reported antitumor and antioxidant effects in fractions rich in tocotrienols (Choi \& Lee, 2009). Tocotrienols possess greater antioxidant potential when compared to others isomers of tocols on iNOS decreasing and COx-2 inhibition. Another important role of tocotrienols consists of improving insulin sensitivity (Simopoulos, 1994). In his perspective, GSO $\gamma$-tocotrienol could explain the potential antioxidant and/or anti-inflammatory effect of the oil.

\section{GSO and physiological aspects of lipids}

A fundamental nutrition aspect of $n-3$ and n-6 PUFA is its essentiality. An animal organism does not have the metabolic pathways to synthesize them, being required by diet supplementation. Linoleic acids (LA) and $\alpha$-linolenic acid (ALA) are essential fatty acids (FA) and play as precursors of other long chain fatty acids (Umesha \& Naidu, 2012). 
<smiles>CC1=C(/C=C/C(C)=C/C=C/C(C)=C/C=C/C=C(C)/C=C/C=C(C)/C=C/C=C(C)/C=C/C2=C(C)CCCC2(C)C)C(C)(C)CCC1</smiles>

$\beta$-carotene<smiles>[R]c1cc([C@H]2Oc3cc(O)cc(O)c3C[C@H]2O)cc(O)c1O</smiles>

Catechin<smiles>[R]c1cc(C2Oc3cc(O)cc(O)c3CC2O)cc(O)c1O</smiles>

Epicatechin<smiles>[R]c1c(C)c2c(c([R])c1O)CC[C@@]([R2])(CCC[C@]([R7])(C)CCCC(C)CCCC([R7])C)O2</smiles><smiles>[R]c1c(C)c2c(c([R])c1O)CC[C@@]([R2])(CC/C=C(/C)CC/C=C(/C)CCC=C(C)C)O2</smiles><smiles>[Z]C1([R])Cc2c(O)cc(O)c([C@H]3c4cc(O)c(O)cc4OC(c4ccc(O)c(O)c4)[C@H]3O)c2OC1c1ccc(O)c(O)c1</smiles><smiles>CCC(CC[C@H](C)[C@H]1CC[C@H]2[C@@H]3CC=C4C[C@@H](O)CC[C@]4(C)[C@H]3CC[C@]21C)C(C)C</smiles><smiles>CC(C)[C@H](C)CC[C@H](C)[C@H]1CC[C@H]2[C@@H]3CC=C4C[C@@H](O)CC[C@]4(C)[C@H]3CC[C@]21C</smiles>

Procianidin<smiles>C/C=C(/CC[C@H](C)[C@H]1CC[C@H]2[C@H]3CC=C4C[C@@H](O)CC[C@]4(C)[C@H]3CC[C@]21C)C(C)C</smiles><smiles>CC[C@H](/C=C/C(C)[C@H]1CC[C@H]2[C@@H]3CC=C4C[C@@H](O)CC[C@]4(C)[C@H]3CC[C@@]21C)C(C)C</smiles>

Figure 1. Principals' minority compounds present in Grape Seed Oil (GSO).

Table 1. Phytosterol Composition (mg/Kg of oil) of Grape Seed Oil (GSO) from the literature.

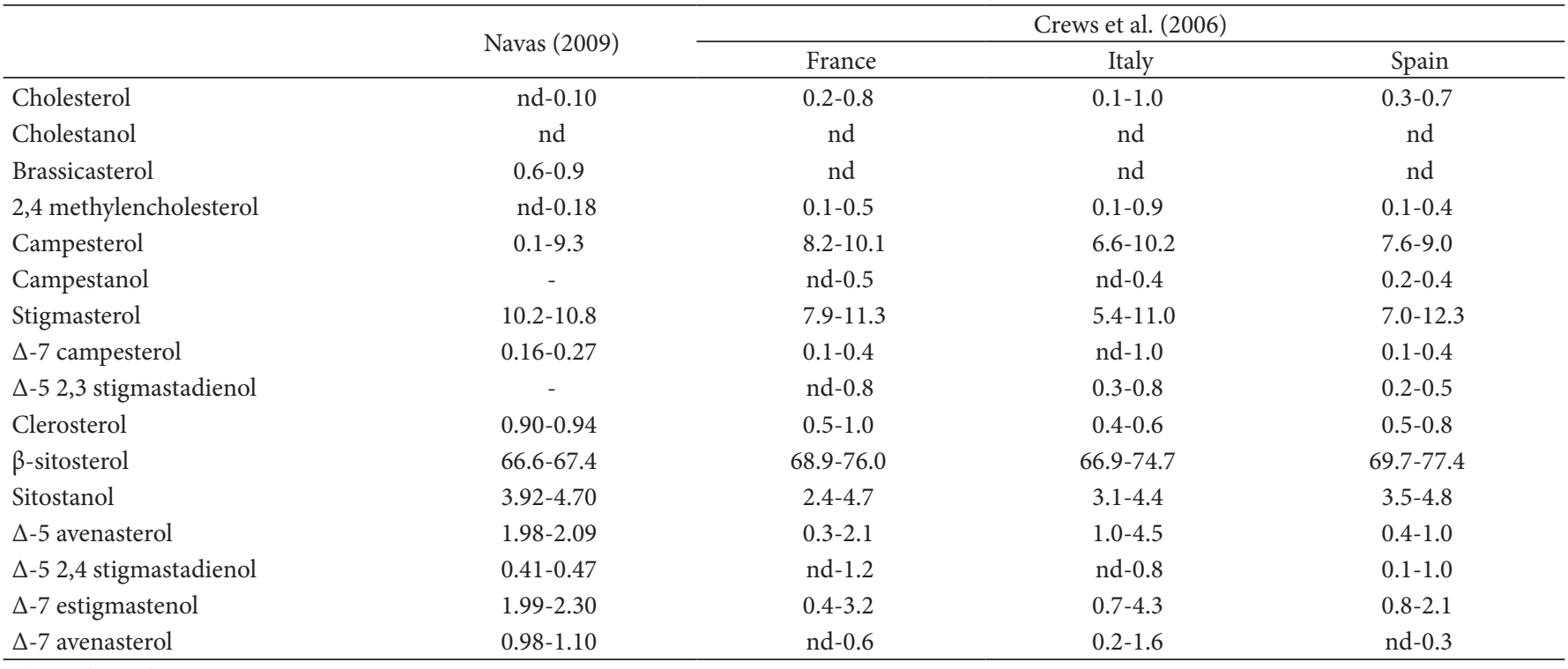


Table 2. Tocopherol and Tocotrienol Composition (mg/Kg of oil) of Grape Seed Oil (GSO) from the literature.

\begin{tabular}{|c|c|c|c|c|c|}
\hline & \multirow{2}{*}{ Navas (2009) } & \multirow{2}{*}{ Fernandes et al. (2013) } & \multicolumn{3}{|c|}{ Crews et al. (2006) } \\
\hline & & & France & Italy & Spain \\
\hline \multicolumn{6}{|c|}{ Tocopherols } \\
\hline$\alpha-T$ & $47-56$ & $86-244$ & $18-229$ & $14-160$ & $\operatorname{tr}-75$ \\
\hline$\gamma-\mathrm{T}$ & $17-29$ & $3-28$ & nd-61 & nd-119 & nd-168 \\
\hline$\Delta-\mathrm{T}$ & nd-3 & $\operatorname{tr}-1$ & nd-47 & nd & nd-69 \\
\hline$\beta$-T3 & - & $4-18$ & nd-67 & nd-22 & nd- 125 \\
\hline$\gamma$-T3 & $482-556$ & $499-1575$ & nd-500 & nd-785 & nd-399 \\
\hline$\Delta-\mathrm{T} 3$ & $13-17$ & $6-18$ & nd & nd & nd- 82 \\
\hline
\end{tabular}

In the literature, the data is still controversial about the effects of different types of FA on health. There are close relation between n-6 PUFA intake and induction of inflammatory response via AA-derived. On the other hand, these FA have important role in homeostasis, regulating resolution and promotion of inflammation in immune response (Raphael \& Sordillo, 2013).

For example, Patterson et al. (2012), suggests an antiinflammatory action of LA, showing levels of C-reactive protein decrease in serum in Japanese men and women; another work reported, by American Heart Association, that consumption of $\mathrm{n}-6$ is related to the reduction in coronary risk of heart disease. The authors confirm that these types of FA should be consumed.

In general, deleterious effects from excessive consumption of PUFA n-6 family are found in the literature, nevertheless, it is not about the n-6 PUFA amount intake and the capacity to modulate cellular metabolism, but it is mainly related to $n-6 / n-3$ ratio. The levels of $n-6$ and $n-3$ and their ratio have been a primary focus of interest because they compete in metabolic pathways that impact cellular responses to physiologic stress.

These enzymes include the desaturases and elongases that generate the highly unsaturated fatty acids (HUFAs) (20- to 22 -carbon fatty acids with 3 to 6 double bonds). HUFAs serve as substrates for synthesis of the eicosanoids; ie, prostaglandins (PG), leukotrienes (LK), thromboxanes (TX), and lipoxins (LX). Competition between $n-3$ and n-6 HUFAs for cyclooxygenases (COx) and lipoxygenases (LOx) determines which types of eicosanoids will be synthesized and thus potentially influence inflammatory, thrombogenic, and vascular responses (Harris et al., 2006).

According to Simopoulos (2003), in Western diet, $n-6 / n-3$ ratio is close to $15-16 / 1$, contrary to which is assumed in a healthy diet (5-4/1). In this way, increasing of $n-6 / n-3$ ratio is a factor of inflammation degree, since derivatives from PUFA n-6 metabolism may initiate and exacerbate inflammatory responses, by pro-inflammatory eicosanoids predominance, suggesting a specific relation between PUFA, immune system and pathogenic diseases (Calder, 2011).

Excessive n-6 PUFA intake, especially LA, is related to some chronic diseases, such as diabetes, greatest risk of coronary disease
(Iso et al., 2002) and propensity to inflammatory conditions (Calder, 2009), like neuroinflammation (Layé, 2010), as well as atherosclerosis, cancer and mastitis (Simopoulos, 2003).

As known, GSO composition is based for LA, and others bioactive compound such as phytosterols. Numerous sources in the literature point to phytosterols role in cholesterol absorption reduction in intestine and, consequently, decrease in plasma cholesterol levels.

According to Nash (2004), GSO consumption of up to 45 grams of oil per day demonstrated increased HDL-cholesterol and reduced LDL-cholesterol levels in respectively 13 and 7\% patients.

Recently, our study group published a work that assessed the effect of chronic consumption of GSO, obtained from the Brazilian market, in biochemical markers and inflammation of healthy rats and we found that GSO consumption did not induce significant metabolic changes, however the contribution to an increase in the levels of HDL was suggested, even a rise in levels of serum lipid peroxidation was noticed (Shinagawa et al., 2015).

Choi et al. (2010) showed GSO supplementation in pigs decreased levels of total fat $30 \%$ to $20 \%$, this being important note for meat quality and closely correlated with lipid metabolism of animals. Kim et al. (2010) studied the effects of GSO on plasma lipid profile in rats and there were also significant reduction in total cholesterol and LDL-cholesterol. Asadi et al. (2010) related the GSO intake with the effects on serum cholesterol, hepatic and muscular; they verified in reduction of serum cholesterol in rats after 10 weeks.

Control of hyperlipidaemia was verified with GSO consumption (Vijaimohan et al., 2006; Gorinstein et al., 2003; Baba et al., 1999) and it has been shown that supplementation with the oil significantly reduced triglycerides and LDL-cholesterol level in rats treated by fat diets.

\section{GSO and oxidative parameters}

Excessive consumption of PUFA in the diet can be deleterious to an organism, due to the increase products such as peroxides and aldehydes. This occurs by presence of double bonds between 
carbon atoms in its chemical structure, being subject to oxidative processes action (Kruger et al., 2010).

Oxidation can lead to damage to cell membranes, exacerbated ROS formation, changes in membrane lipids, proteins, enzymes, carbohydrates and DNA, thereby causing injury of balance and induce oxidative stress (Williams \& Buttriss, 2006). In this sense, it is necessary to promote a delicate balance between oxidation factors and mechanisms of antioxidant defense in biological systems, known as redox homeostasis (Valko et al., 2007).

This defense system is constituted by both enzymatic and non-enzymatic antioxidants. Complex enzymatic system includes superoxide dismutase (SOD), catalase (CAT), glutathione peroxidase (GPx), glutathione reductase (GR) and etc. Non-enzymatic defenses such as reduced glutathione (GSH), bilirubin, uric acid, estrogen, lipoic acid, ascorbic acid, Coenzyme Q, melanin, tocopherols, carotenoids, lycopene, phenolic compounds and flavonoids (Valko et al., 2007).

Antioxidant enzymes mechanism of action is complex and comprises basically of the action of three major enzymes: SOD, CAT and GPx. SOD is an enzyme present in all aerobic organisms and its biological role is the dismutation catalyze of superoxide ions in oxygen $\left(\mathrm{O}_{2}\right)$ and hydrogen peroxide $\left(\mathrm{H}_{2} \mathrm{O}_{2}\right)$. CAT role is based on the control of hydrogen peroxide levels, catalyzing its degradation (transforms $\mathrm{H}_{2} \mathrm{O}_{2}$ formed into water and oxygen). GPx role is another way to eliminate hydrogen peroxide, acting on peroxides removal via reduction to water with concomitant oxidation of GSH to GSSG. GSH can be regenerated by the interaction of oxidized form with nicotinamina adenine triphosphate (NADPH), through GR (Laguerre et al., 2007).

Enzymatic defense system involves a complex chain reaction via intracellular physiological adjustment. An imbalance in redox homeostasis system carries on oxidative stress. This condition is associated with autoimmune diseases, inflammatory neurodegenerative after suppression of modulation by antioxidants (Matsuda \& Shimomura, 2013). We can highlight atherosclerosis (Raposo, 2010), cancer (Reuter et al., 2010), premature aging (Halliwell \& Gutteridge, 1999), neurological disorders (Sayre et al., 2001) and diabetes (Evans et al., 2003).

Antioxidant agents that may alter the oxidative stress state, such as phenolic compounds, flavonoids and vitamin $\mathrm{E}$ have recognized antioxidant potential and they are intrinsic in the oil GSO composition. The major compound found in GSO in the literature is the $\gamma$-tocotrienol composition.

Tocotrienols are closely related chemically with tocopherols; however, they have varying degrees of biological activity. The hypocholesterolemic, antitumor, neuroprotective, and antioxidant activity of tocotrienols or a tocotrienol-rich fraction (TRF) have recently received much attention. Numerous studies have investigated the simultaneous antioxidative and protective activity of tocotrienols against oxidative stress in cultured cells.

Sen et al. (2000) reported that tocotrienols are effective for preventing glutamate-induced neuronal cell death by regulating unique signal transduction. Osakada et al. (2004) demonstrated that tocotrienols purified from palm oil significantly attenuate hydrogen peroxide (H2O2)-induced neurotoxicity. And finally,
Choi et al. (2010) demonstrated the potential protection of the tocotrienols on neuronal cells, using TRF from grape seed as antioxidant defense systems in tert-butyl hydroperoxide (TBHP)induced oxidative injury in HepG2 cells.

\section{GSO and inflammation}

PUFA has a great potential in regulating lipid metabolism and oxidative process due to presence of insaturations (Mancini-Filho, 2010). Consequently, it may induce changes in inflammatory state, by gene expression modulation involved in chronic and low-grade inflammation (Samuel \& Shulman, 2012).

By definition, inflammation is a key component of immune response to certain injury caused in a tissue. This response occurs in an attempt to neutralize and/or eliminate a source of this injury, restoring tissue function. A changing in magnitude control or duration of inflammatory response can cause major tissue damage and contribute to the emergence of diseases (Raphael \& Sordillo, 2013).

In this sense, PUFA amount and type can regulate the complex intracellular signaling system (Lottenberg et al., 2012). The $n-6 / n-3$ ratio contributes to the development of diseases related to inflammation, since the imbalance of the PUFA ratio is capable of initiating and exacerbating inflammatory responses, as explained above. However, although there is a recognized association between the exacerbated PUFA intake and incidence of metabolic diseases, the effective contribution of different types of lipids in metabolic changes is not fully understood (Kumar et al., 2014).

The n-6 PUFA has the ability to modulate inflammatory gene expression by its potential binding to nuclear receptors in cell. Consequently, correlates with a decrease in LXR activity (liver $x$ receptors) and PPAR (peroxisome proliferator-activated receptor) and an increase of NF- $\kappa \mathrm{B}$ activity (nuclear factor kappa B) and of SREBP (sterol regulatory element-binding protein) (Masi et al., 2013; Afman \& Müller, 2012).

Although there are still factors that reconsider pro-inflammatory effect of n-6 PUFA, one of them is related to the product of chain eicosanoids family $n-6$, namely PGE It is able to inhibit production of two cytokines (TNF- $\alpha$ and IL-1) and PGE2 also presents potential to inhibit inflammatory leukotrienes $\left(\mathrm{LTB}_{4}\right)$ via LOX-5 inhibition and induces lipoxins ( $\mathrm{LXA}_{4}$ ) production, responsible for the resolution of inflammation. However AA is not related to PGE2 expression only, which has variable effect cited above. It is also related by lipid mediator's expression like leukotrienes of series 4, TXB2 and PGF2 (Raphael \& Sordillo, 2013; Calder, 2009). These findings reflect both actions pro and anti-inflammatory of the AA.

The relation between PUFA diet, inflammation and increased disease susceptibility is explained also by phospholipid content changes in inflammatory response (monocytes, macrophages and vascular endothelial cells) (Mello et al., 2012). And consequently, increased some genes expression such as tumor necrosis factor $a$ (TNF- $\alpha$ ) and interleukins (the main ones are IL-1, IL-2, IL-6 and IL-8) mediated by NF- $\kappa \mathrm{B}$, increasing plasminogen activator factor inhibitor 1 (PAI-1) (Carvalho et al., 2006). TNF- $\alpha$ is involved 
in modulating the effects of IL-6, which, in turn, is a cytokine pleiotropic and has an important role in inflammatory reactions, stimulating the production of acute phase of inflammation proteins in hepatocytes (Ramalho \& Guimarães, 2008). With the exception of adiponectin, that their production and secretion is inhibited in inflammation condition. Adiponectin is a potent inducer of physiological insulin sensitivity, anti-lipogenic, within antioxidant, anti-inflammatory and anti-fibrotic properties.

Few results from literature were found about the effect of GSO on inflammatory parameters. However, our studies suggested the maintenance of the ratio between anti and pro-inflammatory cytokines on serum, namely TNF- $\alpha / \mathrm{IL}-10$, after consumption of GSO for 65 days in healthy rats.

\section{Conclusion}

GSO consumption is still sluggish in Brazil and, over the years, wine production has increased, generating increasingly large volumes of waste. So, in this context, GSO is a value-added food. It is characterized by high linoleic acid composition, as well as minority compounds such as vitamin $\mathrm{E}$ and phytosterols. Reports in the literature on the benefits of GSO consumption for health are present, such as reduction of biochemical blood parameters, in other words, GSO provide a promising alternative vegetable oil in management of hypercholesterolemia.

\section{Acknowledgements}

To CNPQ process n. 302227/2013-0.

\section{References}

Afman, L. A., \& Müller, M. (2012). Human nutrigenomics of gene regulation by dietary fatty acids. Progress in Lipid Research, 51(1), 6370. http://dx.doi.org/10.1016/j.plipres.2011.11.005. PMid:22155512.

Asadi, F., Shahriari, A., \& Chahardah-Cheric, M. (2010). Effect of longterm optional ingestion of canola oil, grape seed oil, corn oil and yogurt butter on serum, muscle and liver cholesterol status in rats. Food and Chemical Toxicology, 48(8-9), 2454-2457. http://dx.doi. org/10.1016/j.fct.2010.06.012. PMid:20542074.

Baba, N. H., Antoniades, K., \& Habbal, Z. (1999). Effects of dietary canola, olive, and linolenic acid enriched olive oils on plasma lipids, lipid peroxidation, and lipoprotein lipase activity in rats. Nutrition Research 19(4), 601-612. http://dx.doi.org/10.1016/S0271-5317(99)00025-1.

Bail, S., Stuebiger, G., Krist, S., Unterweger, H., \& Buchbauer, G. (2008). Analytical methods: characterization of various grape seed oils by volatile compounds, triacylglycerol composition, total phenols and antioxidant capacity. Food Chemistry, 108(3), 1122-1132.

Beveridge, T. H. J., Girard, B., Kopp, T., \& Drover, J. C. G. (2005). Yield and composition of grape seed oil extracted bysupercritical carbon dioxide and Petroleum ether: varietal effects. Journal of Agricultural and Food Chemistry, 53(5), 1799-1804. http://dx.doi.org/10.1021/ jf040295q. PMid:15740076.

Calder, P. C. (2009). Polyunsaturated fatty acids and inflammatoty processes: new twists in an old tale. Biochimie, 91(6), 791-795. http://dx.doi.org/10.1016/j.biochi.2009.01.008. PMid:19455748.

Calder, P. C. (2011). Fatty acids and inflammation: the cutting edge between food and pharma. European Journal of Pharmacology, 668(1, Suppl 1), S50-S58. PMid:21816146.
Camargo, U. A., Maia, J. D. G., \& Ritschek, P. (2010). Novas cultivares brasileiras de uva. Bento Gonçalves: Embrapa Uva e Vinho.

Cao, X., \& Ito, Y. (2003). Supercritical fluid extraction of grape seed oil and subsequent separation of free fatty acids by high-speed counter-current chromatography. Journal of Chromatography. A, 1021(1-2), 117-124. http://dx.doi.org/10.1016/j.chroma.2003.09.001. PMid:14735980.

Carvalho, M. H. C., Colaço, A. L., \& Fortes, Z. B. (2006). Citocinas, disfunção endotelial e resistência à insulina. Arquivo Brasileiro de Endocrinologia e Metabolismo, 50(2), 304-312. http://dx.doi. org/10.1590/S0004-27302006000200016.

Choi, Y. S., Choi, J. H., Han, D. J., Kim, H. Y., Lee, M. A., Kim, H. W., Lee, J. W., Chung, H. J., \& Kim, C. J. (2010). Optimization of replacing pork back fat with grape seed oil and rice bran fiber for reduced-fat meat emulsion systems. Meat Science, 84(1), 212-218. http://dx.doi.org/10.1016/j.meatsci.2009.08.048. PMid:20374777.

Choi, Y., \& Lee, J. (2009). Antioxidant and antiproliferative properties of a tocotrienol-rich fraction from grape seeds. Food Chemistry, 11(4), 1386-1390.

Chougui, N., Tamendjari, A., Hamidj, W., Hallal, S., Barras, A., Richard, T., \& Larbat, R. (2013). Oil composition and characterization of phenolic compounds of Opuntia ficus-indica seeds. Food Chemistry, 139(1-4), 796-803. http://dx.doi.org/10.1016/j.foodchem.2013.01.054. PMid:23561175.

Crews, C., Hough, P., Godward, J., Brereton, P., Lees, M., Guiet, S., \& Winkelmann, W. (2006). Quantitation of the main constituents of some authentic grape-seed oils of different origin. Journal of Agricultural and Food Chemistry, 54(17), 6261-6265. http://dx.doi. org/10.1021/jf060338y. PMid:16910717.

Empresa Brasileira de Pesquisa Agropecuária - Embrapa. (2013). Embrapa uva e vinho. Brasília: Embrapa. Retrieved from www. cnpuv.embrapa.br.

Evans, J. L., Goldfine, I. D., Maddux, B. A., \& Grodsky, G. M. (2003). Are Oxidative stress activated signaling pathways mediators of insulin resistance and $\beta$-cell dysfunction? Diabetes, 52(1), 1-8. http://dx.doi. org/10.2337/diabetes.52.1.1.

Fernandes, L., Casal, S., Cruz, R., Pereira, J. A., \& Ramalhosa, E. (2013). Seed oils of ten traditional Portuguese grape varieties with interesting chemical and antioxidant properties. Food Research International, 50(1), 161-166. http://dx.doi.org/10.1016/j.foodres.2012.09.039.

Food and Agriculture Organization - FAO. (2012). FAOSTAT. Rome: FAO. Retrieved from http://faostat3.fao.org.

Freitas, L. S., Jacques, R. A., Richter, M. F., Silva, A. L., \& Caramão, E. B. (2008). Pressurized liquid extraction of vitamin E from Brazilian grape seed oil. Journal of Chromatography. A, 1200(1), 80-83. http:// dx.doi.org/10.1016/j.chroma.2008.02.067. PMid:18343386.

Gokturk Baydar, N., \& Akkurt, M. (2001). Oil content and oil quality properties of some grape seeds. Turkish Journal of Agriculture and Forestry, 25(1), 163-168.

Gorinstein, S., Leontowicz, H., Leontowicz, M., Lojek, A., Číž, M., Krzeminski, R., Zachwieja, Z., Jastrzebski, Z., Delgado-Licon, E., Martin-Belloso, O., \& Trakhtenberg, S. (2003). Seed oil improve lipid metabolism and increase antioxidant potential in rats fed diets containing cholesterol. Nutrition Research, 23(3), 317-330. http:// dx.doi.org/10.1016/S0271-5317(02)00532-8.

Guo, L., Wang, L. H., Sun, B., Yang, J. Y., Zhao, Y. Q., Dong, Y. X., Spranger, M. I., \& Wu, C. F. (2007). Direct in vivo evidence of protective effects of grape seed procyanidin fractions and other antioxidants against ethanol-induced oxidative DNA damage in 
mouse brain cells. Journal of Agricultural and Food Chemistry, 55(14), 5881-5891. http://dx.doi.org/10.1021/jf070440a. PMid:17567031.

Halliwell, B., \& Gutteridge, J. M. C. (1999). Free radicals in biology and medicine. 3rd ed. Oxford: Oxford University Press.

Harris, W.; Assaad, B.; Poston, C. (2006). Tissue omega-6/omega-3 fatty acid ratio and risk for coronary artery disease. The American Journal of Cardiology, 98(4), 19-26. http://dx.doi.org/10.1016/j. amjcard.2005.12.023.

Instituto Brasileiro de Geografia e Estatística - IBGE. (2012). Produção agrícola municipal. Rio de Janeiro: IBGE. Retrieved from ftp://ftp. ibge.gov.br/Producao_Agricola

Iso, H., Sato, S., Umemura, U., Kudo, M., Koike, K., Kitamura, A., Imano, H., Okamura, T., Naito, Y., \& Shimamoto, T. (2002). Linoleic acid, other fatty acids, and the risk of stroke. Stroke; a Journal of Cerebral Circulation, 33(8), 2086-2093. http://dx.doi.org/10.1161/01. STR.0000023890.25066.50. PMid:12154268.

Kim, D. J., Jeon, G., Sung, J., Oh, S. K., Hong, H. C., \& Lee, J. (2010). Effect of grape seed oil supplementation on plasma lipid profile in rats. Food Science and Biotechnology, 19(1), 249-252. http://dx.doi. org/10.1007/s10068-010-0035-9.

Kim, Y., Choi, Y., Ham, H., Jeong, H. S., \& Lee, J. (2013). Protective effects of oligomeric and polymeric procyanidin fractions from defatted grape seed on tert-butyl hydroperoxide-induced oxidative damage in HepG2 cells. Food Chemistry, 137(1-4), 136-141. http:// dx.doi.org/10.1016/j.foodchem.2012.10.006. PMid:23200001.

Kobori, C. N., \& Jorge, N. (2005). Caracterização dos óleos de algumas sementes de frutas como aproveitamento de resíduos industriais. Ciência e Agrotecnologia, 29(5), 1008-1014. http://dx.doi.org/10.1590/ S1413-70542005000500014.

Kruger, M. C., Coetzee, M., Haag, M., \& Weiler, H. (2010). Long-chain polyunsaturated fatty acids: selected mechanisms of action on bone. Progress in Lipid Research, 49(4), 438-449. http://dx.doi.org/10.1016/j. plipres.2010.06.002. PMid:20600307.

Kumar, G. S., Swathi, R., \& Krishna, A. G. (2014). Fat-soluble nutraceuticals and their composition in heat-processed wheat germ and wheat bran. International Journal of Food Sciences and Nutrition, 65(3), 327-334. http://dx.doi.org/10.3109/09637486.2013.866640. PMid:24328437.

Lafka, T. I., Sinanoglou, V., \& Lazos, E. S. (2007). On the extraction and antioxidant activity of phenolic compounds from winery wastes. Food Chemistry, 104(3), 1206-1214. http://dx.doi.org/10.1016/j. foodchem.2007.01.068.

Laguerre, M., Lecomte, J., \& Villeneuve, P. (2007). Evaluation of the ability of antioxidant to counteract lipid oxidation: existing methods, new trends and challenges. Progress in Lipid Research, 46(5), 244-282. http://dx.doi.org/10.1016/j.plipres.2007.05.002. PMid:17651808.

Layé, S. (2010). Polyunsaturated fatty acids, neuroinflammation and well being. Prostaglandines, Leukotrienes and Essential Fatty Acids, 82(4-6), 295-303. http://dx.doi.org/10.1016/j.plefa.2010.02.006.

Lottenberg, A. M., Afonso, M. S., Lavrador, M. S. F., Machado, R. M., \& Nakandakare, E. R. (2012). The role of dietary fatty acids in the patology of metabolic syndrome. The Journal of Nutritional Biochemistry, 23(9), 1027-1040. http://dx.doi.org/10.1016/j.jnutbio.2012.03.004. PMid:22749135.

Luque-Rodríguez, J. M., Luque de Castro, M. D., \& Perez-Juan, P. (2005). Extraction of fatty acids from grape seed by superheated hexane. Talanta, 68(1), 126-130.

Lutterodt, H., Slavin, M., Whent, M., Turner, E., \& Yu, L. (2011). Fatty acid composition, oxidative stability, antioxidant and antiproliferative properties of selected cold-pressed grape seed oils and flours.
Food Chemistry, 128(2), 391-399. http://dx.doi.org/10.1016/j. foodchem.2011.03.040. PMid:25212146.

Madawala, S. R. P., Kochhar, S. P., \& Dutta, P. C. (2012). Lipid components and oxidative status of selected specialty oils. Grasas y Aceites, 63(2), 143-151. http://dx.doi.org/10.3989/gya.083811.

Maier, T., Schieber, A., Kammerer, D. R., \& Carle, R. (2009). Residues of grape (Vitis vinifera L.) seed oil production as a valuable source of phenolic antioxidants. Food Chemistry, 112(3), 551-559. http:// dx.doi.org/10.1016/j.foodchem.2008.06.005.

Mancini-Filho, J. (2010). Alimentos funcionais nas doenças cardiovasculares. In N. M. B. Costa \& C. O. B. Rosa (Eds.), Alimentos funcionais componentes bioativos e efeitos fisiológicos (Chap. 18, pp. 297-305). Rio de Janeiro: Editora Rubio.

Masi, L. N., Rodrigues, A. C., \& Curi, R. (2013). Fatty acids regulation of inflammatory and metabolic genes. Current Opinion in Clinical Nutrition and Metabolic Care, 16(4), 418-424. PMid:23739628.

Matsuda, M., \& Shimomura, I. (2013). Increased oxidative stress in obesity: implications for metabolic syndrome, diabetes, hypertension, dyslipidemia, atherosclerosis, and cancer. Obesity Research \& Clinical Practice, 7(5), e330-e341. http://dx.doi.org/10.1016/j.orcp.2013.05.004. PMid:24455761.

Matthäus, B. (2008). Virgin grape seed oil: is it really a nutritional highlight? European Journal of Lipid Science and Technology, 110(7), 645-650. http://dx.doi.org/10.1002/ejlt.200700276.

Mello, L. M. R. (2011). Atuação do Brasil no mercado vitinícola mundial - panorama 2010. Bento Gonçalves: Embrapa Uva e Vinho.

Mello, V. D. F., Kolehmanien, M., Schwab, U., Pulkkinen, L., \& Uusitupa, M. (2012). Gene expression of peripheral blood mononuclear cells as a tool in dietary intervention studies: what do we know so far? Molecular Nutrition \& Food Research, 56(7), 1160-1172. http:// dx.doi.org/10.1002/mnfr.201100685. PMid:22610960.

Nakamura, Y., Tsuji, S., \& Tonogai, Y. (2003). Analysis of proanthocyanidins in grape seed extracts, health foods and grape seed oils. Journal of Health Science, 49(1), 45-54. http://dx.doi.org/10.1248/jhs.49.45.

Nash, D. T. (2004). Cardiovascular risk beyond LDL-C levels. Other lipids are performers in cholesterol story. Postgraduate Medicine, 116(3), 11-15. PMid:15460086.

Navas, P. B. (2009). Chemical composition of the virgin oil obtained by mechanical pressing form several grape seed varieties (Vitis vinifera L.) with emphasis on minor constituents. Archivos Latinoamericanos de Nutricion, 59(2), 214-219. PMid:19719020.

Osakada, F., Hashino, A., Kume, T., Katsuki, H., Kaneko, S., \& Akaike, A. (2004). Alpha-tocotrienol provides the most potent neuroprotection among vitamin $\mathrm{E}$ analogs on cultured striatal neurons. Neuropharmacology, 47(6), 904-915. http://dx.doi.org/10.1016/j. neuropharm.2004.06.029. PMid:15527824.

Pardo, J. E., Fernández, E., Rubio, M., Alvarruiz, A., \& Alonso, G. L. (2009). Characterization of grape seed oil from different grape varieties (Vitis vinifera). European Journal of Lipid Science and Technology, 111(2), 188-193. http://dx.doi.org/10.1002/ejlt.200800052.

Parry, J., Hao, Z., Luther, M., Su, L., Zhou, K., \& Yu, L. (2006). Characterization of cold-pressed onion, parsley, cardamom, mullein, roasted pumpkin, and milk thistle seed oils. Journal of the American Oil Chemists' Society, 83(10), 847-854. http://dx.doi.org/10.1007/ s11746-006-5036-8.

Parry, J., Su, L., Luther, M., Zhou, K., Yurawecz, M. P., Whittaker, P., \& Yu, L. (2005). Fatty acid composition and antioxidant properties of cold-pressed marionberry, boysenberry, red raspberry, and blueberry seed oils. Journal of Agricultural and Food Chemistry, 53(3), 566-573. http://dx.doi.org/10.1021/jf048615t. PMid:15686403. 
Patterson, E., Wall, R., Fitzgerald, G. F., Ross, R. P., \& Stanton, C. (2012). Health implications of high dietary omega- 6 polynsaturated fatty acids. Journal of Nutrition and Metabolism, 2012, 1-16. http://dx.doi. org/10.1155/2012/539426. PMid:22570770.

Peralbo-Molina, A., \& Luque de Castro, M. D. (2013). Potential of residues from the Mediterranean agriculture and agrifood industry. Trends in Food Science \& Technology, 32(1), 16-24. http://dx.doi. org/10.1016/j.tifs.2013.03.007.

Pinelo, M., Fabbro, P., Manzocco, L., Nunez, M. J., \& Nicoli, M. (2005). Optimization of continuous phenol extraction from Vitis vinifera byproducts. Food Chemistry, 92(1), 109-117. http://dx.doi. org/10.1016/j.foodchem.2004.07.015.

Puiggròs, F., Llópiz, N., Ardévol, A., Bladé, C., Arola, L., \& Salvadó, M. J. (2005). Grape seed procyanidins prevent oxidative injury by modulating the expression of antioxidant enzyme systems. Journal of Agricultural and Food Chemistry, 53(15), 6080-6086. http://dx.doi. org/10.1021/jf050343m. PMid:16028999.

Ramalho, R., \& Guimarães, C. (2008). Papel do tecido adiposo e dos macrófagos no estado de inflamação crónica associada à obesidade: implicações clínicas. Acta Medica Portuguesa, 21(5), 489-496. PMid:19187692.

Raphael, W., \& Sordillo, L. M. (2013). Dietary polyunsaturated fatty acids and inflammation: the role of phospholipid biosynthesis. International Journal of Molecular Sciences, 14(10), 21167-21188. http://dx.doi.org/10.3390/ijms141021167. PMid:24152446.

Raposo, H. F. (2010). Efeito dos ácidos graxos n-3 e n-6 na expressão de genes no metabolismo de lipídeos e risco de aterosclerose. Revista Nutrição, 23(5), 871-879. http://dx.doi.org/10.1590/S141552732010000500017.

Reuter, S., Gupta, S. C., Chaturvedi, M. M., \& Aggarwal, B. B. (2010). Oxidative stress, inflammation, and cancer: How are they linked? Free Radical Biology and Medicine, 49(11), 1603-1616.

Revilla, E., Alonso, E., \& Kovac, V.(1997). The content of catechins and procyanidins in grape and wines as affected by agroecological factors and technological practices. In T. R. Watkins (Ed.), Wine: nutritional and therapeutic benefits (pp. 69-80). Washington: American Chemical Society.

Rockenbach, I. I., Rodrigues, E., Gonzaga, L. V., \& Fett, R. (2010). Fatty acid composition of grape (Vitis vinifera L. and Vitis labrusca L.) seed oil. Brazilian Journal of Food Technology, 3, 23-26.

Rubio, M., Alvarez-Ortí, M., Alvarruiz, A., Fernandéz, E., \& Pardo, J. E. (2009). Characterization of oil obtained from grape seeds collected during Berry development. Journal of Agricultural and Food Chemistry, 57(7), 2812-2815. http://dx.doi.org/10.1021/ jf803627t. PMid:19256538.

Samuel, V. T., \& Shulman, G. I. (2012). Mechanisms for insulin resistance: common theads and missing links. Cell, 148(5), 852-871. http:// dx.doi.org/10.1016/j.cell.2012.02.017. PMid:22385956.

Sayre, L. M., Smith, M. A., \& Perry, G. (2001). Chemistry and biochemistry of oxidative stress in neurodegenerative disease. Current Medicinal Chemistry, 8(7), 721-738. http://dx.doi.org/10.2174/0929867013372922. PMid:11375746.

Schieber, A., Muller, D., Rohrig, G., \& Carle, R. (2002). Influence of grape cultivar and processing method on the quality of cold-pressed grape seed oils. Mitteilungen Klosterneuburg, 52(1), 29-33.

Sen, C. K., Khanna, S., Roy, S., \& Packer, L. (2000). Molecular basis of vitamin $\mathrm{E}$ action. Tocotrienol potently inhibits glutamate-induced
pp60(c-Src) kinase activation and death of HT4 neuronal cells The Journal of Biological Chemistry, 275(17), 13049-13055. http://dx.doi. org/10.1074/jbc.275.17.13049. PMid:10777609.

Shi, J., Yu, J., Pohorly, J. E., \& Kakuda, Y. (2003). Polyphenolics in grape seeds - biochemistry and functionality. Journal of Medicinal Food, 6(4), 291-299. http://dx.doi.org/10.1089/109662003772519831. PMid:14977436.

Shinagawa, F. B., Santana, F. C., \& Mancini-Filho, J. (2015). Efeito do óleo de semente de uva prensado a frio nos marcadores bioquímicos e perfil inflamatório de ratos. Revista de Nutrição, 28(1), 65-76. http://dx.doi.org/10.1590/1415-52732015000100006.

Simopoulos, A. P. (1994). Is insulin resistance influenced by dietary linoleic acid and trnas fatty acid? Free Radical Biology \& Medicine, 17(4), 367-372.

Simopoulos, A. P. (2003). The importance of the ratio of omega-6/ omega-3 essential fatty acids: evolutionary aspects. World Review of Nutrition and Dietetics, 92, 1-22. http://dx.doi.org/10.1159/000073788. PMid:14579680.

Tangolar, S. G., Özogul, Y., Tangolar, S., \& Torun, A. (2009). Evaluation of Fatty acid profiles and mineral content of grape seed oil of some grape genotypes. International Journal of Food Sciences and Nutrition, 60(1), 32-39. http://dx.doi.org/10.1080/09637480701581551. PMid:17886077.

Umesha, S. S., \& Naidu, A. (2012). Vegetable oil blends with $a$-linolenic acid rich Garden cress oil modulated lipid metabolism in experimental rats. Food Chemistry, 135(4), 2845-2851. http://dx.doi.org/10.1016/j. foodchem.2012.05.118. PMid:22980881.

Valko, M., Leibfritz, D., Moncol, J., Cronin, M. T. D., Mazur, M., \& Telser, J. (2007). Free radicals and antioxidants in normal physiological function and human disease. The International Journal of Biochemistry \& Cell Biology, 39(1), 44-84. http://dx.doi.org/10.1016/j.biocel.2006.07.001. PMid:16978905.

Vijaimohan, K., Jainu, M., Sabitha, K. E., Subramaniyam, S., Anandhan, C., \& Shyamala Devi, C. S. (2006). Beneficial effects of alpha linolenic acid rich flaxseed oil on growth performance and hepatic cholesterol metabolism in high fat diet fed rats. Life Sciences, 79(5), 448-454. http://dx.doi.org/10.1016/j.lfs.2006.01.025. PMid:16490217.

Vinson, J. A., Mandarano, M. A., Shuta, D. L., Bagchi, M., \& Bagchi, D.(2002). Beneficial effects of a novel IH636 grape seed proanthocyanidin extract and a niacin-bound chromium in a hamster atherosclerosis model. Molecular and Cellular Biochemistry, 240(1-2), 99-103. http:// dx.doi.org/10.1023/A:1020611925819.

Vivancos, M., \& Moreno, J. J. (2008). Effect of resveratrol, tyrosol and $\beta$-sitosterol on oxidased low-density lipoprotein-stimulated oxidative stress, arachidonic acid release and prostaglandin E2 synthesis by RAW 264.7 macrophages. British Journal of Nutrition, 99(6), 1199-1207. http://dx.doi.org/10.1017/S0007114507876203. PMid:18081942.

Wang, Y. J., Thomas, P., Zhong, J. H., Bi, F. F., Kosaraju, S., Pollard, A., \& Fenech, M. (2009). Consumption of grape seed extract prevents amyloid- $\beta$ deposition and attenuates inflammation in brain of an alzheimer's disease Mouse. Neurotoxicity Research, 15(1), 3-14. http://dx.doi.org/10.1007/s12640-009-9000-x.

Williams, C., \& Buttriss, J. (2006). Health benefits of polyunsaturated fatty acids (PUFAs). Improving the fat content of foods (pp. 107-140). Boca Raton: CRC Press. 